\section{Groundwater Quality of Southeastern Wyoming}

\section{Introduction}

Groundwater is an important resource for domestic, municipal, stock, and irrigation uses in southeastern Wyoming. Thirty-seven percent of water used in the tri-County area that includes Laramie, Platte, and Goshen Counties is from groundwater (U.S. Geological Survey, 2009). Most groundwater use in the tri-County area is withdrawn from three primary aquifer groups: Quaternaryage unconsolidated-deposit aquifers, Tertiary-age units of the High Plains aquifer system, and Upper Cretaceous bedrock aquifers (Lance Formation and Fox Hills Sandstone) (fig. 1). Table 1 lists selected physical properties and chemicals found in water, describes their source and importance, and any maximum levels established by the U.S. Environmental Protection Agency, and figure 2 shows concentration ranges for selected physical properties and chemicals in samples collected from the three primary aquifer groups in the tri-County area (Timothy Bartos, U.S. Geological Survey, written commun., 2011, and U.S. Geological Survey, 2011).

\section{Groundwater Supply}

Groundwater is water stored in the crevices, or void spaces, between particles of rocks underground. When groundwater can be extracted in sufficient quantities to constitute a usable supply for people's needs, the deposits or rocks are considered an aquifer. The porosity (size and amount of the void spaces) and the permeability (relative ease with which water can move through void spaces in the rocks) of the aquifer help to determine the speed at which water moves in the aquifer (Waller, 1982). Groundwater is always moving by the force of gravity from the recharge area (where water enters the aquifer) to points of discharge (where water exits the aquifer). Groundwater movement in most areas is slow - a few feet per year (Waller, 1982), but can range from feet per day in the fastest aquifers to feet per million years in the slowest.

\section{Groundwater Quality}

Water interacts with solids, such as minerals and organic matter, liquids, and gasses, as it moves through the hydrologic cycle. Many of these interactions allow chemicals to dissolve into or become suspended in water. The type and concentration of the dissolved chemicals dictate whether the water is suitable for a particular purpose, such as human, livestock, irrigation, or industrial use.

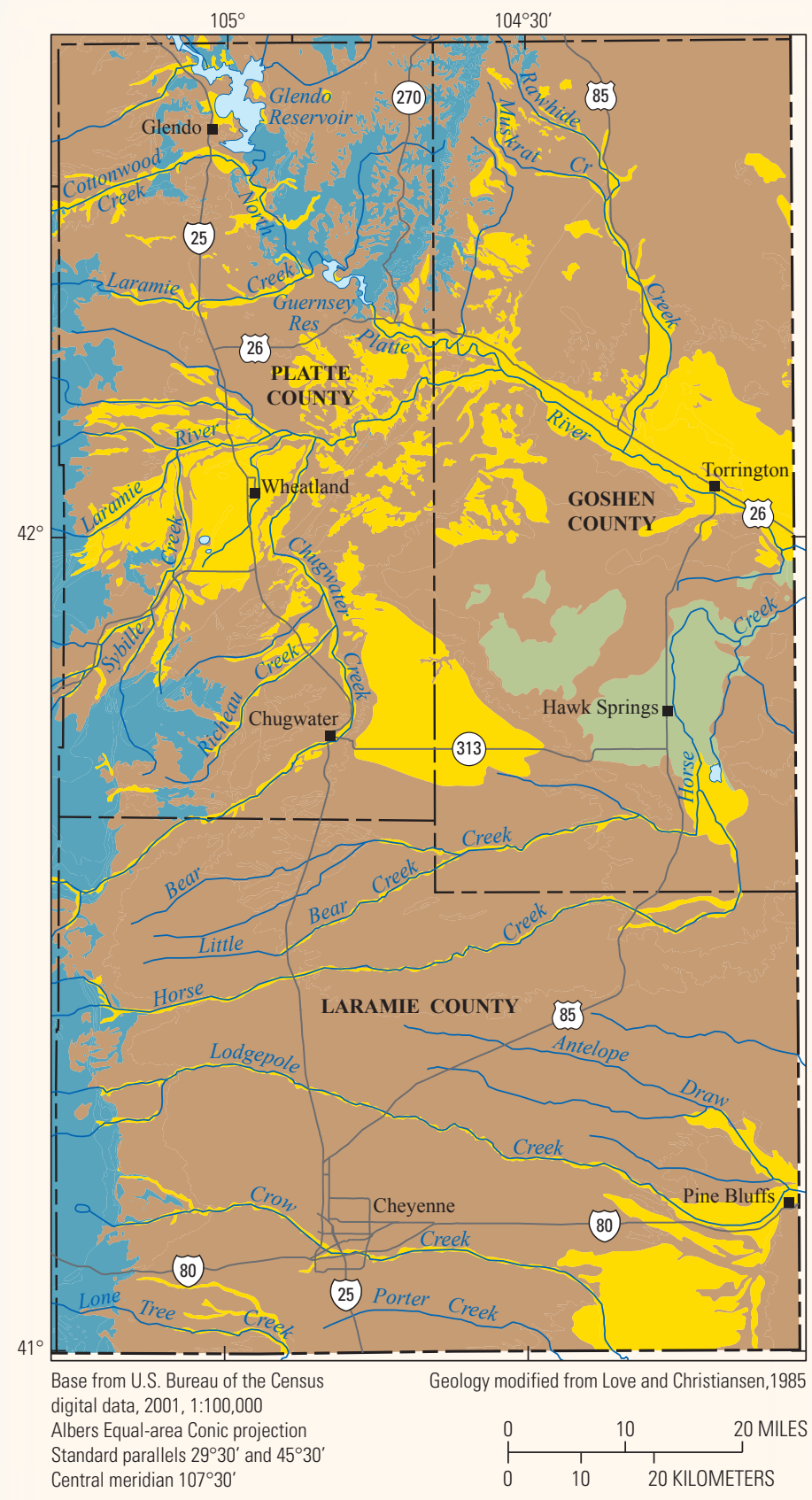

EXPLANATION

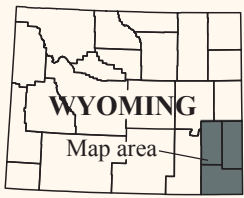

Quaternary-age unconsolidated-deposit aquifers

Tertiary-age units in the High Plains aquifer system

Upper Cretaceous bedrock aquifers

Other-Not discussed in this report

Figure 1. The Tertiary geologic units composing the High Plains aquifer system are the most used source of water in Wyoming (Boughton and others, 2006, fig. 4). Map modified from Bartos and Hallberg (2011). 
Table 1. Water-quality criteria, standards, or recommended levels for selected properties and constituents.

[All standards are from the U.S. Environmental Protection Agency (2011) unless otherwise noted. SMCL, Secondary Maximum Contaminant Level; MCL, Maximum Contaminant Level; action level, level at which 90 percent of samples collected from a water supply must be below in order for the system to be in compliance; $\mathrm{CaCO}_{3}$, calcium carbonate; $\mathrm{N}$, nitrogen; $\mathrm{mg} / \mathrm{L}$, milligrams per liter (parts per million); $\mu \mathrm{g} / \mathrm{L}$, micrograms per liter (parts per billion); --, no limit established; E. coli, Escherichia coli]

\begin{tabular}{|c|c|c|c|}
\hline & $\begin{array}{l}\text { Property or } \\
\text { constituent }\end{array}$ & $\begin{array}{l}\text { Standard or } \\
\text { level }\end{array}$ & Significance \\
\hline \multirow{3}{*}{ 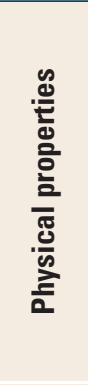 } & $\mathrm{pH}$ & $\begin{array}{l}6.5-8.5 \\
\text { SMCL }\end{array}$ & $\begin{array}{l}\text { A measure of the hydrogen ion concentration; } \mathrm{pH} \text { of } 7.0 \text { indicates a neutral solution, } \mathrm{pH} \text { values } \\
\text { smaller than } 7.0 \text { indicate acidity, } \mathrm{pH} \text { values larger than } 7.0 \text { indicate alkalinity. Water gener- } \\
\text { ally becomes more corrosive with decrease in } \mathrm{pH} \text {; however, excessively alkaline water also } \\
\text { may be corrosive. }\end{array}$ \\
\hline & $\begin{array}{l}\text { Specific conductance } \\
\text { (conductivity) }\end{array}$ & -- & $\begin{array}{l}\text { A measure of the ability of water to conduct an electrical current; varies with temperature. } \\
\text { Magnitude depends on concentration and type of dissolved constituents. Can be used to } \\
\text { determine approximate concentrations of dissolved solids. }\end{array}$ \\
\hline & $\begin{array}{l}\text { Hardness }(\mathrm{mg} / \mathrm{L} \text { as } \\
\left.\quad \mathrm{CaCO}_{3}\right)\end{array}$ & -- & $\begin{array}{l}\text { Related to the soap-consuming characteristics of water, results in formation of scum when soap } \\
\text { is added. May cause deposition of scale in boilers, water heaters, and pipes. }\end{array}$ \\
\hline \multirow{5}{*}{ 号 } & $\begin{array}{l}\text { Calcium plus } \\
\text { magnesium }\end{array}$ & -- & Cause of most of the hardness and scale-forming properties of water (see hardness). \\
\hline & $\begin{array}{r}\text { Sodium plus } \\
\text { potassium }\end{array}$ & -- & $\begin{array}{l}\text { Large concentrations may limit use of water for irrigation and industrial use, and, in combina- } \\
\text { tion with chloride, give water a salty taste. }\end{array}$ \\
\hline & Chloride & $250 \mathrm{mg} / \mathrm{L} \mathrm{SMCL}$ & $\begin{array}{l}\text { Large concentrations increase the corrosiveness of water, and, in combination with sodium, } \\
\text { give water a salty taste. }\end{array}$ \\
\hline & Fluoride & $\begin{array}{l}4.0 \mathrm{mg} / \mathrm{L} \mathrm{MCL} \\
2.0 \mathrm{mg} / \mathrm{L} \mathrm{SMCL}\end{array}$ & $\begin{array}{l}\text { Reduces incidence of tooth decay when optimum fluoride concentrations }(2.0-4.0 \mathrm{mg} / \mathrm{L}) \text { are } \\
\text { present in water consumed by children during the period of tooth calcification. Potential } \\
\text { health effects of long-term exposure to elevated fluoride concentrations include dental and } \\
\text { skeletal fluorosis. }\end{array}$ \\
\hline & Sulfate & $250 \mathrm{mg} / \mathrm{L} \mathrm{SMCL}$ & $\begin{array}{l}\text { Sulfates of calcium and magnesium form a hard scale. Large concentrations of sulfate have a } \\
\text { laxative effect on some people, and, in combination with other ions, give water a bitter taste. }\end{array}$ \\
\hline : & $\begin{array}{l}\text { Nitrate plus nitrite } \\
\quad(\mathrm{mg} / \mathrm{L} \text { as } \mathrm{N})\end{array}$ & $10 \mathrm{mg} / \mathrm{L} \mathrm{MCL}$ & $\begin{array}{l}\text { Concentrations greater than local background levels may indicate pollution from feedlot runoff, } \\
\text { sewage, or fertilizers. It is generally assumed that typical background concentrations of } \\
\text { nitrate plus nitrite rarely exceed } 2 \mathrm{mg} / \mathrm{L} \text { as } \mathrm{N} \text {. }\end{array}$ \\
\hline \multirow{5}{*}{ 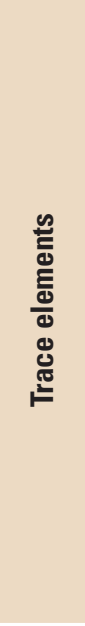 } & Copper & $\begin{array}{l}1,300 \mu \mathrm{g} / \mathrm{L} \\
\text { (action level) }\end{array}$ & $\begin{array}{l}\text { Essential to metabolism; copper deficiency in infants and young animals results in nutritional } \\
\text { anemia. Large concentrations of copper are toxic and may cause liver damage. Moderate } \\
\text { levels of copper (near the action level) can cause gastrointestinal distress. }\end{array}$ \\
\hline & Iron & $300 \mu \mathrm{g} / \mathrm{L} \mathrm{SMCL}$ & $\begin{array}{l}\text { Forms rust-colored sediment; stains laundry, utensils, and fixtures reddish brown. Objection- } \\
\text { able for food and beverage processing. Can promote growth of certain kinds of bacteria that } \\
\text { clog pipes and well openings. }\end{array}$ \\
\hline & Lead & $\begin{array}{c}15 \mu \mathrm{g} / \mathrm{L} \\
\text { (action level) }\end{array}$ & $\begin{array}{l}\text { A cumulative poison; toxic in small concentrations. Can cause lethargy, loss of appetite, consti- } \\
\text { pation, anemia, abdominal pain, gradual paralysis in muscles, and death. }\end{array}$ \\
\hline & Manganese & $50 \mu \mathrm{g} / \mathrm{L} \mathrm{SMCL}$ & $\begin{array}{l}\text { Causes gray or black stains on porcelain, enamel, and fabrics. Can promote growth of certain } \\
\text { kinds of bacteria that clog pipes and well openings. }\end{array}$ \\
\hline & Zinc & $\begin{array}{l}5,000 \mu \mathrm{g} / \mathrm{L} \\
\mathrm{SMCL}\end{array}$ & $\begin{array}{l}\text { Essential and beneficial in metabolism; its deficiency in young children or animals will retard } \\
\text { growth and may decrease general body resistance to disease. Seems to have no ill effects } \\
\text { even in fairly large concentrations }(20,000-40,000 \mu \mathrm{g} / \mathrm{L}) \text {, but can impart a metallic taste or } \\
\text { milky appearance to water. Zinc in drinking water commonly is derived from galvanized } \\
\text { coatings of piping. }\end{array}$ \\
\hline \multirow{2}{*}{ 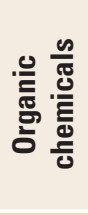 } & $\begin{array}{r}\text { Total petroleum } \\
\text { hydrocarbons }\end{array}$ & $\begin{array}{l}\text { Varies by specific } \\
\text { compound }^{1}\end{array}$ & $\begin{array}{l}\text { Any mixture of organic compounds consisting entirely of hydrogen and carbon found in crude } \\
\text { oil. Compounds occur naturally as part of oil deposits, but are not typical in high-quality } \\
\text { groundwater. }\end{array}$ \\
\hline & Pesticides & $\begin{array}{l}\text { Varies by specific } \\
\text { compound }^{1}\end{array}$ & $\begin{array}{l}\text { Used to kill harmful animals or plants. Compounds are not naturally present in groundwater. } \\
\text { Concentrations affecting human health vary depending on pesticide. }\end{array}$ \\
\hline 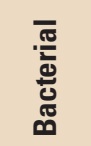 & Bacteria, E. coli & 0 colonies & $\begin{array}{l}\text { E. coli is found in the intestines of warm-blooded animals. Most } E \text {. coli strains are harmless to } \\
\text { humans, but organism can be used to indicate water contamination from fecal material. }\end{array}$ \\
\hline
\end{tabular}

${ }^{1}$ Specific human-health standards or levels can be found in U.S. Environmental Protection Agency (2011). 

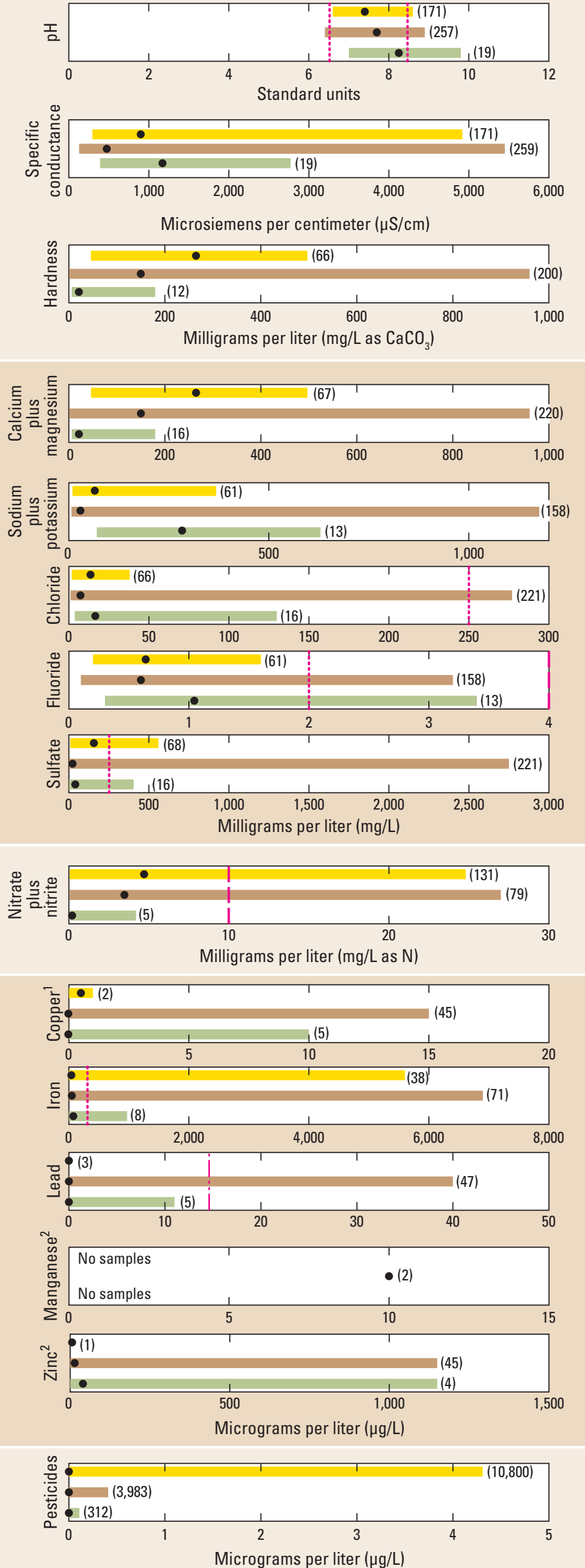

A delicate balance of dissolved chemicals is necessary to have good-quality drinking water, as some dissolved chemicals are helpful (such as calcium and fluoride) and provide a preferred taste, whereas some can cause health problems. The U.S. Environmental Protection Agency (USEPA) (2011) has established levels of what is considered safe for many chemicals in publicly supplied drinking water. Table 1 (modeled from Carter and others, 2002) lists selected physical properties and chemicals found in water, describes their source and importance, and any maximum levels established by the USEPA. The USEPA has two types of levels, the Maximum Contaminant Level (MCL), which is established to protect human health and is enforceable, and the Secondary Maximum Contaminant Level (SMCL), which is not enforceable and is generally related to aesthetic properties of drinking water. Although these regulations apply to public drinking-water supplies and not to private domestic water sources, the MCLs and SMCLs can be used as a reference for evaluating the quality of water.

The quality of groundwater is determined by the dissolved chemicals in the water at the beginning of the journey from the land surface to the aquifer, as well as by the chemicals encountered in the ground before it reaches the aquifer. Human activities on the land surface and underground can affect groundwater quality. For example: infiltrating water can dissolve pesticides and nutrients into the groundwater in areas

\section{EXPLANATION}

\section{Range of values in Quaternary-age unconsolidated-deposit aquifers Range of values in Tertiary-age units in the High Plains aquifer system \\ Range of values in Upper Cretaceous bedrock aquifers \\ - - - U.S. Environmental Protection Agency (2011) Maximum Contaminant Level (MCL) \\ U.S. Environmental Protection Agency (2011) Secondary Maximum Contaminant Level (SMCL) \\ - - - - U.S. Environmental Protection Agency (2011) action level}

- Median value

$(10,800)$ Number of samples

All standards are from the U.S. Environmental Protection Agency (2011). MCL, Maximum Contaminant Level; SMCL, Secondary Maximum Contaminant Level; action level, level at which 90 percent of samples collected from a water supply must be below in order for the system to be in compliance; $\mathrm{CaCO}_{3^{\prime}}$ calcium carbonate; N, nitrogen; $\mathrm{mg} / \mathrm{L}$, milligrams per liter (parts per million) $\mu \mathrm{g} / \mathrm{L}$, micrograms per liter (parts per billion); U.S. Environmental Protection Agency (USEPA) MCLs exist for some pesticides, but have varying values, therefore no MCL is shown for pesticide data; insufficient data exist to create plots for bacteria and total petroleum hydrocarbons.

${ }^{1}$ Copper has an action level of $1,300 \mu \mathrm{g} / \mathrm{L}$, which is greater than the plot's $\mathrm{x}$ axis. ${ }^{2}$ Manganese and zinc each have a USEPA SMCL, but SMCL values are greater than the plot's $x$-axis $(50 \mu \mathrm{g} / \mathrm{L}$, manganese, and 5,000 $\mu \mathrm{g} / \mathrm{L}$, zinc).

Figure 2. Range of minimum to maximum concentrations and median concentration of selected properties and constituents from water samples collected in Quaternaryage unconsolidated-deposit aquifers, Tertiary-age units in the High Plains aquifer system, and Upper Cretaceous bedrock aquifers (1943-2010). 
where pesticides and fertilizers are applied; underground fuel storage tanks can leak and allow petroleum components to enter groundwater. At certain concentrations, these chemicals can affect health. Although some petroleum products occur naturally, they are not common in the three primary aquifer groups used to provide drinking water in Laramie, Platte, and Goshen Counties. Additionally, the quality of groundwater is determined by the characteristics of the rocks composing the aquifer it resides in, and the length of time the water resides in the aquifer, as it continues to slowly dissolve minerals from the rocks. Therefore, different aquifers will often have different water-quality characteristics.

\section{Understanding Your Well's Water Quality}

To determine if water from a particular well can be used for an intended purpose, a groundwater sample needs to be collected and sent to a laboratory for analysis. Analytical results can then be compared to drinking-water standards or levels to help determine suitability for intended uses. It is important to realize that a single water sample represents one point in time and that water-quality conditions may change with time. Regular sampling of water from a given well is the most effective way to evaluate potentially varying conditions. A way to help determine if the water from a well is typical for Laramie, Platte, and Goshen Counties is to compare it to groundwater samples collected in the same geographic area. Figure 2 shows concentration ranges for selected physical properties and chemicals in samples collected from the three primary aquifer groups in the tri-County area (1943-2010) (Timothy Bartos, U.S. Geological Survey, written commun., 2011 and U.S. Geological Survey, 2011). The median, or middle value of the samples collected, is shown in addition to an MCL or SMCL if one has been established. For several chemicals, the lowest value and the median are close together (fig. 2). This can happen if there are a few high values for a chemical, with many more low values. If an individual water sample shows a particular chemical or property at a level greater than a drinking-water standard, then additional tests are suggested. Local, State, and Federal agencies listed in the box below can assist with interpreting your well's groundwater quality.

\section{References Cited}

Bartos, T.T. and Hallberg, L.H., 2011, Generalized potentiometric surface map, estimated depth to water, and estimated saturated thickness of the High Plains aquifer system, MarchJune 2009, in Laramie County, Wyoming: U.S. Geological Survey Scientific Investigations Map 3180, 1 sheet.

Boughton, G.K., Remley, K.R., and Bartos, T.T., 2006, Estimated water use in Wyoming during 2000: U.S. Geological Survey Fact Sheet 2006-3099, 4 p.

Carter, J.M., Driscoll, D.G., and Williams, J.E., 2002, Atlas of water resources in the Black Hills area, South Dakota: U.S. Geological Survey Hydrologic Investigations Atlas 747, $120 \mathrm{p}$.

Love, J.D., and Christiansen, A.C. (compilers), 1985, Geologic map of Wyoming: U.S. Geological Survey Geologic Map, 3 sheets, scale 1:500,000.

U.S. Environmental Protection Agency, 2011, National primary drinking water regulations, accessed July 25, 2011, at http:// water.epa.gov/drink/contaminants/index.cfm.

U.S. Geological Survey, 2009, Estimated use of water in the United States county-level data for 2005, accessed June 27, 2011, at http://water.usgs.gov/watuse/data/2005/index.html.

U.S. Geological Survey, 2011, National Water Information System, accessed June 27, 2011, at http://nwis.waterdata. usgs.gov/wy/nwis.

Waller, R.M., 1982, Ground water and the rural homeowner: U.S. Geological Survey General Interest Publication, 36 p.

By Cheryl A. Eddy-Miller, U.S. Geological Survey, and Liberty Blain, Laramie County Conservation District

\section{For More Information about Groundwater}

Laramie County Conservation District: general outreach and education, and a web site related to this fact sheet, 11221 U.S. Highway 30, Cheyenne, WY 82009, telephone (307) 772-2600, http://www.lccdnet.org/.

Platte County Resource District: general outreach and education, 1502 Progress Court, Wheatland, WY 82201, telephone (307) 322-9060, http://www.conservewy.com/pcrd.html.

Wyoming State Engineer's Office: Groundwater Division, well permits and water-rights issues, 122 West 25 th Street, 4th Floor-East, Cheyenne, WY 82002, telephone (307) $777-$ 6163, http://seo.state.wy.us/GW/index.aspx.

Wyoming Department of Environmental Quality, Water Quality Division: water-quality regulation, 122 West 25th Street, 4th Floor-West, Cheyenne, WY 82002, telephone (307) 777-7781, http://deq.state.wy.us/wqd/.

\section{Wyoming Department of Agriculture: agricultural issues, 2219 Carey Avenue, Cheyenne, WY 82002, telephone (307) 777-7321, http://wyagric.state.wy.us/.}

Wyoming Oil and Gas Conservation Commission: oil and gas industry compliance, 2211 King Boulevard, Casper, WY 82602, telephone (307) 234-7147, http://wogcc.state.wy.us/.

U.S. Geological Survey: water-quality and water-level data, 521 Progress Circle, Suite 6, Cheyenne, WY 82007, telephone (307) 778-2931, http://wy.water.usgs.gov/.

This project has been funded in part with grants from the Southeast Wyoming Resource Conservation and Development Council and the Wyoming Department of Agriculture.

Prepared by the Denver and Rolla Publishing Service Centers 